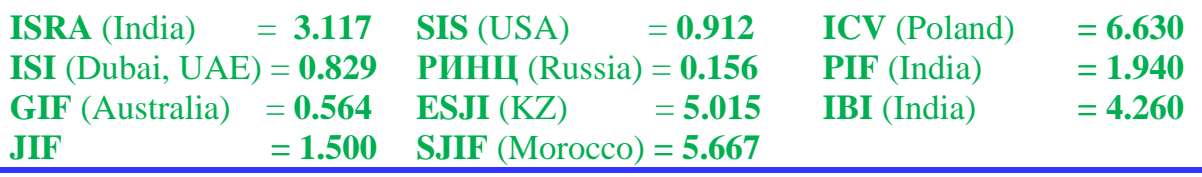

SOI: $\underline{1.1 / \text { TAS }}$ DOI: $\underline{10.15863 / \text { TAS }}$

International Scientific Journal Theoretical \& Applied Science

p-ISSN: 2308-4944 (print) e-ISSN: 2409-0085 (online)

Year: 2018 Issue: 12 Volume: 68

Published: $26.12 .2018 \quad$ http://T-Science.org

SECTION 13. Geography. History. Oceanology. Meteorology.
QR - Issue

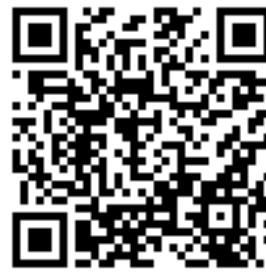

QR - Article

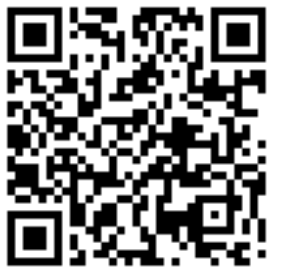

Umidakhon Maripjonovna Ahmedova the teacher of Humanitarian Sciences department Andizhan branch of Tashkent State Agrarian University, Republic of Uzbekistan

\title{
SOME REFORMS AND THEIR RESULTS WHICH ARE TAKING TO DEVELOP THE AGRICULTURE OF UZBEKISTAN
}

Abstract: In this article, some reforms and their results which have been taken on the branch of agriculture of Uzbekistan in the independence years are analyzed by the help of historical resources.

Key words: Uzbekistan, agriculture, agrarian reforms, cotton planting, livestock breeding, farm households.

Language: English

Citation: Ahmedova, U. M. (2018). Some reforms and their results which are taking to develop the agriculture of Uzbekistan. ISJ Theoretical \& Applied Science, 12 (68), 239-241.

Soi: http://s-o-i.org/1.1/TAS-12-68-34 Doi: crossef https://dx.doi.org/10.15863/TAS.2018.12.68.34

\section{Introduction.}

It is of great importance to modernize and develop of the agricultural branch of Uzbekistan nowadays. Because, the agriculture of the Republic is the most important and the most becoming mechanized branch in the national economy, and is required the demand of people who need food products, and the raw materials in the food industry branches. It includes the initial and complete processing of reproducing agricultural plants and animal products and it is of big importance to provide for people's material prosperities. Reforming the agriculture and some items to support the safety of the food no doubt is remained one of the main tasks before us. The main attention in the agriculture of the republic is country's climate, soil and water and raw resources and also on the basis of using the farming culture that has been gathered for many centuries with productively raising farm products.

On the farming grain growing, cotton growing, rice growing, fruit growing, grapes growing, cultivation of melons, vegetable growing branches, in the livestock breeding and cattle breeding, sheep breeding, karakul-sheep breeding, goat breeding, poultry, horse breeding, beekeeping, silkworm breeding branches are in activity. It should be observed that Uzbekistan is on the $4^{\text {th }}$ place to provide the total cotton growing and exporting the cotton fiber stands on the $2^{\text {nd }}$ place ( after the USA ) [1]. In the republic high-grade fruit growing, grapes growing and vegetable growing are prepared and exported to the foreign countries. Uzbekistan is famous with its high-quality cocoon and karakul skin in the world. Republic has already reached the wheat independence and is exporting to abroad. According to its forms of property, private (peasant and farming, private enterprises, associations, state experimental and also experimental farms) inhabitants' personal subsidiary farms (especially, raising the agricultural products for their necessity in the private plot) sectors are existed. It is known that in the time of the USSR, in the reason of making a decision one cotton managing on the agriculture of Uzbekistan, in the late 1987s the cotton was planted more than watering $60 \%$ of the fields, totally 2107.7 thousand hectares [2]. In the period of the Soviet authority, it was aimed to build a colonial and tyrant society in Uzbekistan. First of all, the administrators paid attention to the development of agriculture in the Republic. Because Uzbekistan being within the former Union specialized to grow cotton, became the source of raw material and $3 / 2$ of the cotton was carried to the center in carrying out it, water and irrigation were important. According to the colonial character of the agrarian policy of the Soviet authority, irrigation and land-reclamation of the Republic developed intensively.

As a result, scientific proved changing cropping system was completely unsettled, mineral fertilizers, herbicides and especially, pesticides which are dangerous for the health of humankind used more without measures, ecological and reclamation conditions were broken in the farming fields and soil components. After having reached the independence 


\begin{tabular}{|c|c|c|c|c|c|c|}
\hline \multirow{4}{*}{ Impact Factor: } & ISRA (India) & $=3.117$ & SIS (USA) & $=0.912$ & ICV (Poland) & $=6.630$ \\
\hline & ISI (Dubai, UAE & $=0.829$ & РИНЦ (Russia) & $=0.156$ & PIF (India) & $=1.940$ \\
\hline & GIF (Australia) & $=0.564$ & ESJI (KZ) & $=\mathbf{5 . 0 1 5}$ & IBI (India) & $=4.260$ \\
\hline & JIF & $=1.500$ & SJIF (Morocco) & $=5.667$ & & \\
\hline
\end{tabular}

of Uzbekistan, a new era began putting into practice deep reforms on the agriculture of the country. According to analyze the economical reforms on the agriculture step by step in our republic we can divide following basic directions [3]:

- proprietary and componental relations;

- reforms using the land;

- reforms using water and water resources relations;

- reforms finance- credit, tax and insurance branches;

- reforms the prices system;

The government of the republic paid attention to develop the market relations in the country's most important branch of the agricultural economy, to turn to the forms into the independent proprietary, releasing property from the state possession and being in privatization and organizing the activity matters of the peasant household and farming agriculture [4]. The parliament of the republic passed laws about deep turns which created legally on the agriculture. Supplying those decisions to put into action consistently in practice on the branch of agriculture in the mechanism of market in short time, remained the relations from Former Union to the property being wastefully and to be done away with and becoming distant from disorders to the property, and it is of great importance putting into a practice a freedom of initiative and business activity [5]. Some reforms which are putting into practice not only on the agricultural spheres, but some branches that serve to this, branches which reproduce the productions, it includes producing and social infrastructural joints and also reforming the external trade branches. From the early years of our independence, deeply based on an agrarian policy was made by the leading of our first president about developing relations to the ground and to the water in our state and reforming the agricultural factors are played the most important role. Bringing to an end consistent and widen surround reforms in the independence years some fundamental structural changes happened in the agrarian sector of the economy [6].

In the villages different kinds of property forms appeared. An attitude of the people to the property and to the land began changing. Taking and developing forms of the agrarian policy in the republic in the economical reforms to put into practice are connected and done with the dialectical process. That is why, new agrarian relations in our country which influence taking and developing shapes in the state policy it is suitable to research dividing into four stages conditionally [7]:

The first Stage ( 1991- 1995 ) Providing with the economical independence of the country, for the purpose of stability the agriculture and reconstructing it, initial social-political and legal basis are created by passing from the planned economy into the systematical market economy. Releasing the property from the state possession and being in privatization was paid attention to, 1066 state farms were finished and on their basis collective farms were organized. Livestock breeding farming, orchards and vineyards, small ground plots and also green houses were in privatization.

The second Stage (1996- 2000) In these years, a modern mechanism of running the farming began to be created. Likewise, a modern legal foundation of taking to develop the agrarian relations were completely created [8]. Developing the farming, some durable basis and guarantees created in order to the economical and financial independence of the farm agriculture "The ground codex", "About releasing the property from the state possession ", “ About the peasant household ", " About the farm agriculture " decisions and as well as the other law and standard- legislative documents were accepted. The structural policy in agriculture and first of all the local specialized conforming field of planting was realized with the acceptable way; running the household and organizational- legal forms were change completely.

The third Stage (2004- 2007) In the middle of these time a new edition of the decision "About the farm agriculture" a decision of the Ministers Council of the republic of Uzbekistan "Farm associations which gets damage and works with passive profitable and having no future changing into farming agricultures" and was organized the state leasing company "Uzmeliomashleasing" gave wide opportunities deepening the economical reforms. Structural reconstructing the farm associations and on basis of them the process of organizing the farming agricultures were held [9]; the property owners farm class was created; in the system of activity on livestock and peasant household and also economical relations of the agriculture and branches which serve to this were changed.

The fourth Stage (since 2008) In this stage, the first president of the republic of Uzbekistan made a decision "About accepting the measures plots of the land which depends on the possession to the farm agricultures" D- 3077- numbered order [10], "Measures against the decay" programme, “ Development and flourishing of the village "year were done some tasks according to the state programme. Increasing to produce the consumer goods; to increase a number of farming agricultures in exchange for getting high profit; supplying of using the land and water; getting reached doing the agrotechnical measures in time effectively; supplying enough property using credits from the commercial banks; first of all, it is profit (or bank credits) at the expense of techniques and other things were achieved to buy. 


\begin{tabular}{|c|c|c|c|c|c|c|}
\hline \multirow{4}{*}{ Impact Factor: } & ISRA (India) & $=3.117$ & SIS (USA) & $=0.912$ & ICV (Poland) & $=6.630$ \\
\hline & ISI (Dubai, UAI & $=0.829$ & РИНЦ (Russia) & $=0.156$ & PIF (India) & $=1.940$ \\
\hline & GIF (Australia) & $=0.564$ & ESJI (KZ) & $=5.015$ & IBI (India) & $=4.260$ \\
\hline & JIF & $=1.500$ & SJIF (Morocco) & $=5.667$ & & \\
\hline
\end{tabular}

\section{Conclusion.}

As to say in conclusion, the most important task to put into practice on the agriculture of the republic was to solve the attitude to the property to the ground. The right of owned property to the ground not in bureaucracy, not in given red -tape mongering, but it should be put into action in modernized and be based on the market relations. According to give the grounds as a rent for a long time to be developed the farming and peasants households will be a firmed direction.

\section{References:}

1. (2017). Uzbekistan's Development Strategy for 2017- 2021 has been adopted following public consultation. (p.129). Tashkent: newspaper, spiritual enlightenment.

2. (2016). SAMUz - "Educational programme according to run the farming agriculture in Uzbekistan" teaching - methodological manual around the project. (p.29). Tashkent.

3. (2012). 2012 was the year of raising the development of our country on the new stage. Teaching manual. Tashkent: Teacherpublishing house.

4. (2005). Juridical and financial basis of farming activity. (p.7). Tashkent: University.
5. (2014). The economy of peasants and farming agricultures. (p.22). Tashkent.

6. (2010). Putting an order the activity of the farming. (p.4). Tashkent: New generation age.

7. (2006). National encyclopedia of Uzbekistan"12 $2^{\text {th }}$ volume. (p.281). State Scientific Publishing House.

8. Mirzaabdullaeva, M. (2010). Putting an order the activity of the farming. (p.25). New generation age.

9. (2015). Khalq suzi.

10. (2017). O'zbekiston ovozi. 